International Scientific Organization http://iscientific.org/

Chemistry International

www.bosaljournals.com/chemint/

\title{
Heavy metal contamination and water quality of selected fish ponds at Sunyani, Ghana: A comparison with WHO standards
}

\author{
Selina A. Saah ${ }^{1,}{ }^{*}$, David Adu-Poku ${ }^{1}$ and Nathaniel 0. Boadi ${ }^{2}$ \\ ${ }^{1}$ Department of Chemical Sciences, University of Energy and Natural Resources, Sunyani, Ghana \\ ${ }^{2}$ Department of Chemistry, Kwame Nkrumah University of Science and Technology, Kumasi, Ghana \\ *Corresponding author's E. mail: Selina.saah@uenr.edu.gh
}

\section{A R T I C L E I N F O}

\section{Article type:}

Research article

Article history:

Received January 2021

Accepted April 2021

July 2021 Issue

Keywords:

Heavy metals

Physicochemical analysis

Chemical oxygen demand

Biochemical oxygen demand

Fish ponds

Bioaccumulation

\section{A B S T R A C T}

Optimum fish production is greatly dependent on the physical, chemical and biological qualities of water. Hence, successful fish pond management requires an in-depth understanding of water quality. A study to assess heavy metal $(\mathrm{Cr}, \mathrm{Cd}$, $\mathrm{Mn}, \mathrm{Pb}$ and $\mathrm{Zn}$ ) contamination and physicochemical parameters of water samples from eight selected fish ponds in Sunyani, Ghana, was conducted. The parameters included temperature, $\mathrm{pH}$, salinity, total hardness, electrical conductivity (EC), chemical oxygen demand (COD) and biological oxygen demand (BOD). The results revealed detectable $\mathrm{Mn}$ and $\mathrm{Zn}$ levels in all the selected fish ponds; with Mn levels in three ponds being significantly higher than the World Health Organization (WHO) recommended limit $(<0.500 \mathrm{mg} / \mathrm{L})$. Of the three samples, which showed detectable $\mathrm{Cr}$ and $\mathrm{Cd}$ levels, concentrations of two exceeded the permissible limits. $\mathrm{Pb}$ was below the detection limit in all the samples whilst $\mathrm{Cu}$ levels detected in two of the ponds were below the permissible limit. The investigated physicochemical parameters had the following ranges: temperature 26-29 ${ }^{\circ} \mathrm{C}$, pH 5.8-8.2, BOD 0.3-20 mg/L, Total Dissolved Solids (TDS) 37-249 $\mathrm{mg} / \mathrm{L}$, EC 73.67-498 $\mu \mathrm{S} / \mathrm{cm}$, total hardness $0.8-5.7 \mathrm{mg} / \mathrm{L}$, salinity $0.03-0.22 \mathrm{psu}$ and COD 2.9-9.7 mg/L. Most of these values were within WHO recommended levels. The findings suggest that regular monitoring of the heavy metal load is necessary to guard against long-term effects of its presence in the water, influencing fish and human uptake.

(C) 2021 International Scientific Organization: All rights reserved.

Capsule Summary: Water quality parameters and heavy metal pollution of selected fish ponds in Sunyani have been analyzed and compared with WHO standards.

Cite This Article As: S. A. Saah, D. Adu-Poku and N. O. Boadi. Heavy metal contamination and water quality of selected fish ponds at Sunyani, Ghana: A comparison with WHO standards. Chemistry International 7(3) (2021) 181-187.

https://doi.org/10.5281/zenodo.4899629

\section{INTRODUCTION}

The challenge of providing food and livelihood to a population well over 9 billion people by the middle of the twenty-first century has been enormous for human societies
(FAO, 2018). Food and agriculture are key to addressing this global challenge and fisheries and aquaculture directly linked to many Sustainable Development Goals (SDGs). More importantly, SDG 14 seeks to conserve and sustainably use the oceans, seas and marine resources. According to the FAO Director-General, Jose Graziano da Silva, (2018) 'since 1961 
the annual global growth in fish consumption has been twice as high as population growth, demonstrating that the fisheries and aquaculture sector is crucial in meeting the FAO's goal of a world without hunger and malnutrition'. The Food and Agriculture Organization (FAO) further estimates that almost $20 \%$ more fish will be eaten by 2030 . Although fish supply will increase in all regions, the per capita fish consumption is anticipated to decrease in Africa, a concern for food security on the continent.

Aquaculture is a fairly new business in Ghana, and its pattern is growing across the country, especially, in the Ashanti, Volta, Central, Western, Bono and Ahafo regions. The operators' pattern on a subsistence scale applies semiintensive and extensive systems to culture fish in earthen ponds, dams, dugouts, ponds and reservoirs (Amenyogbe et al., 2018). Holding systems used by these farmers are floating cages, earthen ponds and concrete tanks. Fish feed generally includes cereal bran such as wheat bran, rice bran and maize bran which are commonly accessed from the local market.

It is established that fish productivity in aquaculture largely depends on feed consumption and quality (Sandre et al., 2017); stocking density (M'balaka et al., 2012), biotic factors such as sex, age, and genetic variance, and abiotic factors such as water chemistry, temperature, photoperiod (Makori et al., 2017) and oxygen level (Bhatnagar and Devi, 2017). Therefore, an understanding of water quality, which is determined by abiotic factors such as temperature, dissolved oxygen (DO), transparency, turbidity, water color, carbon dioxide, $\mathrm{pH}$, alkalinity, hardness, unionized ammonia, nitrite, nitrate, biological oxygen demand (BOD), plankton population among others is essential for the effective management of fish ponds. Water is the natural habitat of fishes and other aquatic organisms, and in fish farming, water quality is vital for optimal production and fish welfare; especially when done in an artificial setting (Mandal et al., 2017; Oluyemi et al., 2010). According to Boyd (1990), water quality is the most important limiting factor in fish culture. Water quality parameters that are commonly measured and monitored to maintain the health and well-being of fish include temperature, $\mathrm{pH}$, alkalinity, dissolved oxygen (DO), carbon dioxide, ammonia, hardness, nitrites and total dissolved solids (TDS) (Jaeger and Aubin, 2018; Sehar et al., 2014). Each of these factors has a standard value for fish culture and can directly or indirectly affect fish health (James, 2000). While some parameters such as alkalinity and hardness are relatively steady, others like dissolved oxygen and $\mathrm{pH}$ vary regularly. Fluctuations in some parameters may affect other parameters. For instance, $\mathrm{pH}$ is interdependent with other parameters such as alkalinity and hardness (Klontz, 1993). The quality of a fish pond is also affected by pollutants from anthropogenic activities such as metals, pesticides and other chemicals released into the environment and ultimately in water bodies (Biney, 1986). Recent studies show that fish accumulate heavy metals from food, water and sediments (Adeyeye, 1996). Although some of these heavy metals in their right concentrations are beneficial, others can be toxic to aquatic organisms and humans. For example, zinc is an essential element and plays a vital role in maintaining cytoplasmic veracity. However, at higher concentrations, zinc causes structural damages to fish that affects their growth and survival. In humans, high concentrations of zinc can cause skin annoyances, stomach cramps, vomiting, nausea, damage to the pancreas and disturbed protein metabolism (Sehar et al., 2014). Although the most common water sources used for aquaculture are wells, springs, rivers and lakes, some people also practice artificial fish farming. Artificial fish farming is generally done in ponds controlled to achieve optimum fish production conditions (Eze and Ogbaran, 2010). In this study, heavy metal contamination and water quality parameters suitable for optimum fish production of eight selected fish ponds in the Sunyani metropolis were investigated and compared with standard values for fish culture.

\section{MATERIAL AND METHODS}

\section{Study area}

The study was conducted at Berlin Top, a suburb of Sunyani. Berlin top shares boundary with Odumasi to the north, Fiapre to the west, Baakoniaba to the south, and Sunyani to the east within the Sunyani west district. The vegetation of this locality consists of grasses with scattered low trees. The climate is tropical, with an average temperature of $25.7^{\circ} \mathrm{C}$. The soil is enriched with minerals that support the cultivation of staple foods such as yam, cocoyam, maize etc.

\section{Sampling}

Water samples from eight tilapia rearing ponds were randomly taken weekly for three weeks and analyzed. At each location, the samples were taken from two or three different sites. In all, eight samples were analyzed. Whilst some parameters were measured onsite, others were performed in the laboratory.

\section{Physicochemical analysis}

The temperature, conductivity, salinity, $\mathrm{pH}$ and total dissolved solids of the various samples were measured directly onsite using a Hanna HI 9829 multiparameter meter. Measurements for each parameter were taken according to the manufacturer's instructions. The chemical oxygen demand, biological oxygen demand and turbidity were determined as reported by APHA (1992).

\section{Heavy metal analysis}

The concentrations of manganese, cadmium, copper, chromium, lead and zinc were analyzed using atomic absorption spectroscopy (AAS) after the samples had been digested following standard procedures reported in the literature (Sehar et al., 2014; Mensah et al., 2016). Typically, $5 \mathrm{ml}$ of $\mathrm{HNO}_{3}$ was added to $100 \mathrm{ml}$ of the water sample in a 
$250 \mathrm{ml}$ beaker. The resultant mixture was heated until the volume reduced to approximately $20 \mathrm{ml}$. Digestion was continued by heating and adding of $\mathrm{HNO}_{3}$ until a clear solution was obtained. The solution was cooled and filtered into a $50 \mathrm{ml}$ volumetric flask and made up to the mark. A blank solution was prepared with the same procedure without the sample. Analysis for concentrations of $\mathrm{Mn}, \mathrm{Cu}, \mathrm{Zn}$, $\mathrm{Cr}, \mathrm{Pb}$ and $\mathrm{Cd}$ was done with Atomic Absorption Spectrometer (Analytik Jena: NovAA 400 P) in replicate and the standard deviations determined.

\section{RESULTS AND DISCUSSION}

\section{Heavy metals}

Metals are released into water bodies from natural sources as well as human activities (Sehar et al., 2014). Despite the adverse effects of metals on the environment, some are essential to living organisms. These metals are of particular interest due to their adverse effects and ability to bioaccumulate in aquatic ecosystems (Soylak and Erdogan, 2006). Fishes in the human diet are considered as a rich source of essential metals (iron, zinc, copper) and polyunsaturated fatty acids (predominantly omega- 3 fatty acids) (Sehar et al., 2014). There is, therefore, the need to ensure that fishes are wholesome for human consumption.

The presence and concentrations of six heavy metals were analyzed in all the eight ponds. The results are summarized in Table 1.

The results revealed detectable levels of $\mathrm{Mn}$ and $\mathrm{Zn}$ in all the selected fish ponds. Mn concentration ranged from 0.3143 to $2.127 \mathrm{mg} / \mathrm{L}$ with Pond B1 recording the highest whilst $\mathrm{Zn}$ was between 0.0222 and $0.6640 \mathrm{mg} / \mathrm{L}$ (Table 1). Aside from $\mathrm{Mn}, \mathrm{Cd}$, and $\mathrm{Cr}$ in a few of the ponds where the observed concentrations were higher, the values reported in this study are generally comparable to similar studies (Adeyemi and Ugah, 2017; Onuoha, 2017). The levels of Mn in Pond U2 (0.7203 mg/L), Pond B1 $(2.1270 \mathrm{mg} / \mathrm{L})$ and Pond B2 (1.9980 mg/L) were above the desired limit $(<0.500 \mathrm{mg} / \mathrm{L})$ according to WHO recommendations. Of the three samples (U3, A1 and A2) which showed detectable levels each of $\mathrm{Cr}$ and $\mathrm{Cd}$, concentrations in $\mathrm{A} 1$ and $\mathrm{A} 2$ exceeded the permissible limits of $0.1 \mathrm{mg} / \mathrm{L}$ and 0.005 $\mathrm{mg} / \mathrm{L}$ respectively. $\mathrm{Cr}$ levels in $\mathrm{A} 1$ and $\mathrm{A} 2$ were 56.8 and $38.1 \%$ whilst Cd were 3,136 and 2,406 \% higher than their permissible limits. Although this study cannot establish whether the detected $\mathrm{Cr}$ is in the $3+$ or $6+$ oxidation state, the EPA classification of $\mathrm{Cr}$ (VI) as a known human

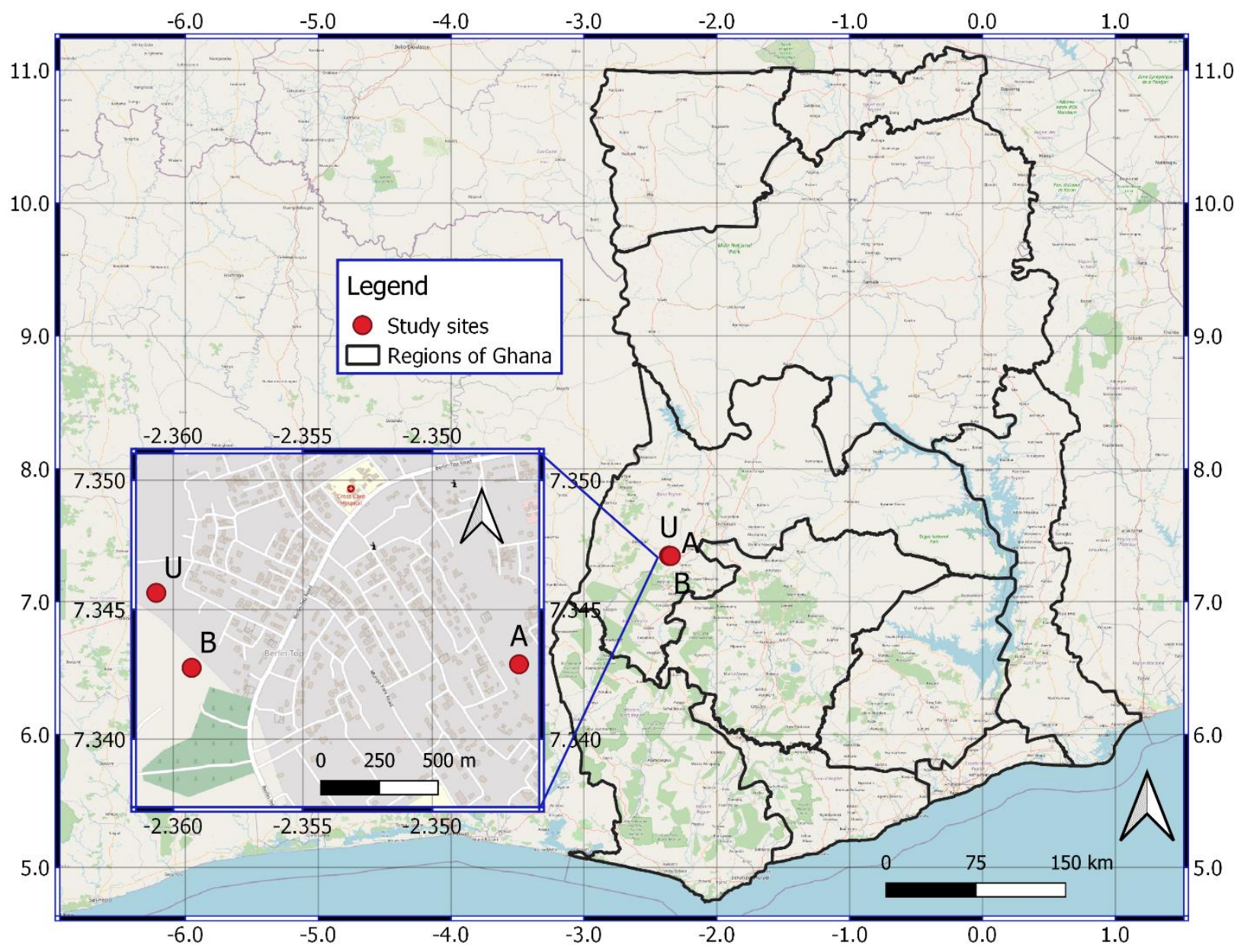

Fig. 1: Map of Ghana with inset showing the study area 
carcinogen raises a serious concern about its high levels. However, $\mathrm{Pb}$ was not detected in any of the samples whilst copper was detected only in Ponds B1 and B3 with concentrations of 0.0108 and $0.0233 \mathrm{mg} / \mathrm{L}$, respectively, which were within the WHO permissible limits. The undetected levels of $\mathrm{Pb}$ and low levels of $\mathrm{Zn}$ and $\mathrm{Cu}$ notwithstanding, these metals are known to bioaccumulate and biomagnifies within the different trophic levels in the food chain. Benthic and pelagic fish have been reported to bioaccumulate $\mathrm{Zn}, \mathrm{Pb}, \mathrm{Cd}$ and $\mathrm{Cu}$ in gills, liver and flesh (Rahman et al., 2012). Zn bioaccumulation in the gills and biomagnification in the food chain have equally been reported (Sehar et al., 2014).

Metals such as $\mathrm{Cr}, \mathrm{Pb}$ and $\mathrm{Cd}$ are non-essential and bioaccumulate in tissues and body of aquatic organisms in higher concentration than in the water (Abumourad et al., 2013; Healey, 2009). This causes serious health problems in humans. For instance, cadmium can bind with proteins to form complexes that can distort the purifying property of the kidney (Sastry and Gupta, 1979). The detection of Cd and $\mathrm{Cr}$ in some water samples pose a threat to both the aquatic organisms and humans. A possible contamination source could be the runoff from adjacent agricultural areas since these metals are often present in fertilizers or pesticides.

\section{Temperature}

Like amphibians and reptiles, fishes are coldblooded, implying they tend to have the same body temperature as the surrounding water. Fishes have poor tolerance to temperature. At higher water temperatures, water holds less dissolved oxygen, and this affects fish respiration and metabolism. This causes stress and a high mortality rate (Boyd, 1990; Chang et al., 2019; Devi et al., 2017). The temperature of the fish ponds analyzed in this study ranged from 26 to $29{ }^{\circ} \mathrm{C}$ (Table 2), which were within the range recommended by WHO $\left(15-30{ }^{\circ} \mathrm{C}\right)$. These temperatures have been confirmed by research earlier reported in the literature (Zanatta et al., 2010).

\section{pH}

The $\mathrm{pH}$ of water is an index of hydrogen ion activity of water. A drop or rise of one $\mathrm{pH}$ unit indicates a ten-fold increase or decrease in hydrogen ion concentration. $\mathrm{pH}$ has also been found to vary at different times of the day in surface water systems; low before sunrise and highest in the middle of the day (Kestemont et al., 2015). The $\mathrm{pH}$ values of the investigated fish ponds ranged from 5.80 to 8.20 over the three weeks (Table 2). According to Swingle (Swingle, 1967) and Hepher and Pruginin (Hepher and Pruginin, 1981), a $\mathrm{pH}$ range of 6.5 to 9 at daybreak is considered best for pond fish culture. Even though fishes may survive at a $\mathrm{pH}$ as low as 4 or as high as 11, fish production would drastically reduce (Devi et al., 2017). Ponds U1, U3, B1-3 had lower $\mathrm{pH}$ values required for optimum fish production in the third week of sampling. This can be due to waste deposit (eg: decaying organic matter) in the pond and can cause a high rate of fish mortality.

\section{Electrical conductivity}

The conductivity of water is simply the measure of how well it conducts electricity. Although WHO has no guideline for EC in ponds, Stone and Thomforde (2004), reported that electrical conductivity of $30-500 \mu \mathrm{S} / \mathrm{cm}$ is acceptable for pond fish culture. From the results, the EC for all the ponds were within the acceptable levels. Since conductivity is directly related to the concentration of conductive ions in water, increasing the amount of dissolved salts and inorganic materials like chlorides, sulphate and carbonate compounds would increase the electrical conductivity. Aside from electrical conductivity being the basis for salinity and TDS calculations, it is useful in monitoring early water system changes (Langland and Cronin, 2003).

\section{Salinity}

Salinity is a major feature that affects the density and population growth of aquatic organisms (Jamabo, 2008). The amount of salt dissolved in a water body is defined as the total concentration of electrically charged ions present in the water. Salinity, therefore, contributes enormously to the electrical conductivity of the water. The values obtained for the fish ponds fell within the standard range of 0-1.0 psu recommended by WHO.

Table 1: Heavy metal concentrations $(\mathrm{mg} / \mathrm{L})$ in the selected fish ponds in Sunyani

\begin{tabular}{lccccccccc}
\hline Heavy & Pond & Pond & Pond & Pond & Pond & Pond & Pond & Pond & Permissible \\
metal & U1 & U2 & U3 & B1 & B2 & B3 & A1 & A2 & Limits (mg/L) \\
\hline $\mathrm{Mn}$ & 0.4396 & 0.7203 & 0.3143 & 2.127 & 1.998 & 0.3960 & 0.2917 & 0.1903 & 0.5 \\
$\mathrm{Cu}$ & BDL & BDL & BDL & 0.0108 & BDL & 0.0233 & BDL & BDL & 1.5 \\
$\mathrm{Zn}$ & 0.0222 & 0.0381 & 0.0540 & 0.3115 & 0.0812 & 0.1686 & 0.6640 & 0.6460 & 15 \\
$\mathrm{Cr}$ & BDL & BDL & 0.0009 & BDL & BDL & BDL & 0.1568 & 0.1381 & 0.1 \\
$\mathrm{~Pb}$ & BDL & BDL & BDL & BDL & BDL & BDL & BDL & BDL & 0.1 \\
$\mathrm{Cd}$ & BDL & BDL & 0.0009 & BDL & BDL & BDL & 0.1568 & 0.1203 & 0.005 \\
\hline
\end{tabular}

$\mathrm{BDL}=$ Below Detection Limit 
Table 2: Physicochemical properties of water samples from selected fish ponds in Sunyani

\begin{tabular}{|c|c|c|c|c|c|c|c|c|c|}
\hline Pond & Week & $\begin{array}{c}\text { Temperature } \\
\left({ }^{\circ} \mathrm{C}\right)\end{array}$ & $\mathrm{pH}$ & $\begin{array}{c}\text { EC } \\
(\mu \mathrm{S} / \mathrm{cm})\end{array}$ & $\begin{array}{c}\text { Salinity } \\
\text { (psu) }\end{array}$ & $\begin{array}{c}\text { TDS } \\
(\mathrm{mg} / \mathrm{L})\end{array}$ & $\begin{array}{l}\text { Hardness } \\
(\mathrm{mg} / \mathrm{L})\end{array}$ & $\begin{array}{c}\text { BOD } \\
(\mathrm{mg} / \mathrm{L})\end{array}$ & $\begin{array}{c}\text { COD } \\
(\mathrm{mg} / \mathrm{L})\end{array}$ \\
\hline \multirow[t]{3}{*}{ Pond A1 } & 1 & 26 & 6.60 & 116 & 0.05 & 58 & 2.0 & 1.60 & 5.20 \\
\hline & 2 & 28 & 6.70 & 115 & 0.06 & 57 & 1.7 & 2.00 & 5.40 \\
\hline & 3 & 26 & 6.71 & 87.7 & 0.07 & 43.7 & 2.1 & 0.30 & 3.85 \\
\hline \multirow[t]{3}{*}{ Pond A2 } & 1 & 27 & 7.13 & 73.7 & 0.03 & 37 & 2.4 & 1.45 & 5.30 \\
\hline & 2 & 28 & 6.80 & 107 & 0.06 & 54 & 1.4 & 1.75 & 5.15 \\
\hline & 3 & 26 & 6.89 & 91.8 & 0.08 & 47.5 & 1.8 & 0.60 & 4.00 \\
\hline \multirow[t]{3}{*}{ Pond B1 } & 1 & 27 & 7.36 & 452 & 0.22 & 226 & 4.5 & 1.60 & 5.30 \\
\hline & 2 & 29 & 7.34 & 436 & 0.21 & 218 & 4.5 & 1.60 & 6.00 \\
\hline & 3 & 26 & 5.80 & 251 & 0.15 & 125.4 & 2.5 & 0.30 & 4.15 \\
\hline \multirow{3}{*}{ Pond B2 } & 1 & 28 & 6.99 & 281 & 0.13 & 140 & 4.7 & 1.65 & 2.90 \\
\hline & 2 & 28 & 7.71 & 328 & 0.16 & 164 & 3.6 & 1.40 & 3.50 \\
\hline & 3 & 26 & 6.24 & 326 & 0.19 & 162.1 & 1.5 & 0.40 & 4.30 \\
\hline \multirow[t]{3}{*}{ Pond B3 } & 1 & 28 & 6.99 & 299 & 0.14 & 149 & 5.0 & 1.85 & 5.30 \\
\hline & 2 & 29 & 7.25 & 327 & 0.16 & 163 & 3.0 & 1.25 & 4.50 \\
\hline & 3 & 26 & 6.01 & 377 & 0.17 & 215 & 3.0 & 0.30 & 4.05 \\
\hline \multirow[t]{3}{*}{ Pond U1 } & 1 & 27 & 8.25 & 305 & 0.14 & 153 & 3.5 & 1.75 & 7.50 \\
\hline & 2 & 28 & 7.70 & 340 & 0.17 & 170 & 3.5 & 1.50 & 7.80 \\
\hline & 3 & 26 & 6.06 & 498 & 0.11 & 249 & 1.0 & 0.70 & 4.25 \\
\hline \multirow[t]{3}{*}{ Pond U2 } & 1 & 26 & 7.47 & 197 & 0.09 & 98 & 3.1 & 1.25 & 7.80 \\
\hline & 2 & 28 & 7.36 & 192 & 0.09 & 96 & 5.7 & 1.50 & 9.70 \\
\hline & 3 & 26 & 7.11 & 151.8 & 0.10 & 76.1 & 0.8 & 0.50 & 4.00 \\
\hline \multirow[t]{3}{*}{ Pond U3 } & 1 & 26 & 7.38 & 186 & 0.09 & 93 & 3.3 & 1.75 & 8.90 \\
\hline & 2 & 29 & 7.31 & 182 & 0.09 & 90 & 2.8 & 1.80 & 8.80 \\
\hline & 3 & 26 & 6.21 & 152.8 & 0.10 & 77.3 & 1.4 & 0.70 & 4.35 \\
\hline WHO (2020) & & $15-30$ & $6.5-8.5$ & - & $0-10$ & 500 & $50-100$ & $3-20$ & $3-20$ \\
\hline
\end{tabular}

\section{Total dissolved solids}

The value of TDS for the various ponds ranged from 37 to $249 \mathrm{mg} / \mathrm{L}$ as reported in Table 2. Ponds A1 and A2 have the least dissolved substances. This is consistent with the low EC values for the said ponds. All these values were within the permissible values for water qualify for fish ponds.

\section{Hardness}

Total hardness is simply a measure of the calcium and magnesium concentrations in water. Even though other di and tri-valent ions may contribute to total hardness, they are mostly present in insignificant quantities. From the results, an appreciable decrease in total hardness was observed in the third week of sampling. Overall, the values obtained in the study were below the standard range of 50$100 \mathrm{mg} / \mathrm{L}$ suitable for aquaculture as recommended by the WHO, which implies that the water is soft. It has been reported that total hardness values less $20 \mathrm{mg} / \mathrm{L}$ can cause stress and less mineral content in fishes (Dinesh et al., 2017). This can, however, be corrected by liming the pond.

\section{BOD and COD}

BOD is the measurement of the amount of dissolved oxygen needed by organisms to break down the organic matter present in a given water sample under aerobic conditions at a specific temperature over a certain period. According to Boyd and Thunjai (2003), the standard range of BOD suitable for most freshwater species is between 3 and 20 $\mathrm{mg} / \mathrm{L}$. The BOD of the various ranged from 0.3 to 2.0 (Table 2 ). The values recorded were all below the lower limit. This could be as a result of overstocking of fish in the pond causing a shortage of oxygen. Low dissolved oxygen concentration has been noted as a major cause of stress, poor appetite, slow growth, disease susceptibility and mortality in aquaculture animals (Makori et al., 2017). The BOD of the ponds, however, can be increased by using mechanical aeration (Warish et al., 2017). The COD values ranging from 2.9 to $9.7 \mathrm{mg} / \mathrm{L}$ were within WHO's recommended values. Earlier research on the COD for fish ponds has reported values less than $20 \mathrm{mg} / \mathrm{l}$ (Warish et al., 2017).

\section{CONCLUSIONS}

The water quality of selected fish ponds in Sunyani has been studied. Based on the findings, temperature, salinity, COD and TDS were all found to be in the optimum range recommended for fish growth in all the three sample areas whilst total hardness and BOD were below the acceptable range. The presence of heavy metal such as chromium and cadmium in some of the ponds pose a health risk to aquatic 
organisms and humans. The present study suggests that appropriate steps be undertaken at the investigated ponds to maintain and improve the water quality for fish culture at regular intervals and monitor the effect of these changes on the fish's growth. This would help ensure the well-being of the aquatic biome, humans and the environment.

\section{ACKNOWLEDGEMENTS}

The authors acknowledge Dr. Kwame Oppong Hackman of the University of Energy and Natural Resources for his assistance in this study.

\section{REFERENCES}

Abumourad, I.M.K., Authman, M.M.N., Abbas, W.T., 2013. Heavy metal pollution and metallothionein expression: A survey on Egyptian tilapia farms. Journal of Applied Sciences Research 9, 612-619.

Adeyemi, M.M., Ugah, I.A., 2017. Evaluation of Concentration of some Heavy Metals in Water, Soil, and Fish from Ponds in Lugbe, Idu and Kuje in the Federal Capital Territory (FCT), Abuja, Nigeria. Journal of Environmental Science, Toxicology Food Technology 2, 39-43.

Adeyeye, E., 1996. Determination of major elements in Illisha africana fish, associated water and soil sediments from some freshwater ponds. Bangladesh Journal of Scientific Industrial Research 31, 171-184.

Amenyogbe, E., Chen, G., Wang, Z., Lin, M., Lu, X., Atujona, D., 2018. A Review of Ghana's Aquaculture Industry. Journal of Aquaculture Research and Development 9, 8-13.

APHA, 1992. Standard methods for the examination of water and wastewater. USA: American Public Health Association.

Bhatnagar, A., Devi, P., 2013. Water quality guidelines for the management of pond fish culture. International Journal of Environmental Sciences 3,1980-2009.

Biney, C.A., 1986. Preliminary physico-chemical studies of lagoons along the Gulf of Guinea in Ghana. Tropical Ecology 27, 147-156.

Boyd, C.E., 1990. Water quality in ponds for aquaculture. Agriculture Experiment Station, Auburn University, Alabama. Pp. 1-482.

Boyd, C.E., Thunjai, T., 2003. Concentrations of major ions in waters of inland shrimp farms in China, Ecuador, Thailand, and the United States. Journal of the World Aquaculture Society 34, 524-532.

Chang, H.A., Saeromi, L., Ho, M.S., Jae, R.P., Jin, C.J., 2019. Assessment of water quality and thermal stress for an artificial fish shelter in an urban small pond during early summer. Water 11, 139-157.

Devi, P.A., Padmavathy, P., Aanand, S., Aruljothi, K., 2017. Review on water quality parameters in freshwater cage fish culture. International Journal of Applied Research 3, 114-120.

Dinesh, K.G., Karthik, M., Rajakumar, R., 2017. Study of seasonal water quality assessment and fish pond conservation in Thanjavur, Tamil Nadu, India, Journal of Entomology and Zoology Studies 5, 1232-1238.

Eze, V.C., Ogbaran, I.O., 2010. Microbiological and physicochemical characterizes of fish pond water in Ughelli Delta State, Nigeria. International Journal of Current Research 8, 82-87.

Food and Agriculture Organization 2018. State of world fisheries and aquaculture-meeting the sustainable development goals, Rome, Italy.

Healey, N., 2009. Lead toxicity, vulnerable subpopulations and emergency preparedness. Radiation Protection Dosimetry 134, 143-151.

Hepher, B., Pruginin, Y., 1981. Commercial fish farming. A Wiley Interscience Publication, New York 1-261.

Jaeger, C., Aubin, J., 2018. Biological and physico-chemical dataset from different fishponds systems related to IMTA: fish, water and sediment. Sea Open Scientific Data Publication, https//doi.10.17882/56675.

Jamabo, N.A., 2008. Ecology of Tympanotonus fuscatus (Linnaeus, 1758) in the mangrove swamps of the Upper Bonny River, Niger Delta, Nigeria. PhD. Thesis, Rivers State University 1-340.

James, M.E., 2000. Water quality and recalculating aquaculture systems. Aquaculture Systems Technologies, LLC. New Orleans, LA 16-28.

Kestemont, P., Dabrowski, K., Summerfelt, R.C., 2015. Biology and culture of percid fishes: principles and practices. Springer 1-919.

Klontz, G.W., 1993. Environmental requirements and environmental diseases of salmonids. Phiadelphia 1-342.

Langland, M., Cronin, T., 2003. A summary report of sediment processes in Chesapeake Bay and watershed, water resources investigations report 03-4123. New Cumberland, Pennsylvania: US Geological Survey. DOI. 10.3133/wri034123.

M'balaka, M., Kassam, D., Rusuwa, B., 2012. The effect of stocking density on the growth and survival of improved and unimproved strains of Oreochromis shiranus. Egypt Journal of Aquaculture Research 38, 205-211.

Makori, A.J., Abuom, P.O., Kapiyo, R, Anyona, D.N., Dida, G.O., 2017. Effects of water physico-chemical parameters on tilapia (Oreochromis niloticus) growth in earthen ponds in Teso North Sub-County, Busia County. Fisheries and Aquatic Sciences 20, 1-10.

Mandal, R., Rai, S., Shrestha, M., Jha, D., Pandit, N., Rai, S., 2017. Water quality and red bloom algae of fish ponds in three different regions of Nepal. Our Nature 14, 71-77.

Mensah, M.B., Boadi, N.O., Baa-Poku, F., Wemegah, D.D., Badu, M., Saah, S.A., Osei-Dei, B., 2016. Physicochemical properties and levels of heavy metals in selected rivers within the Kumasi International Journal of Science and Technology 5, 616-623.

Oluyemi, E.A., Adekunle, A.S., Adenuga, A.A., Makinde, W.O., 2010. Physico-chemical properties and heavy metal content of water sources in Ife North Local Government Area of Osun State, Nigeria. African Journal of Environmental Science Technology 4, 691-697. 
Onuoha, S.C., 2017. Assessment of metal contamination in aquaculture fish ponds south eastern, Nigeria. World Applied Science Journal 35, 124-127.

Rahman, M.S., Molla, A.H., Saha, N., Rahman, A., 2012. Study on heavy metals levels and its risk assessment in some edible fishes from Bangshi River, Savar, Dhaka, Bangladesh. Food Chemistry 134, 1847-1854.

Sandre, L.C.G., Buzollo, H., Nascimento, T.M.T., Neira, L.M., Jomori, R.K., Carneiro, D.J., 2017. Productive performance and digestibility in the initial growth phase of tambaqui (Colossoma macropomum) fed diets with different carbohydrate and lipid levels. Aquaculture Reports 6, 2834.

Sastry, K.V., Gupta, P.K., 1979. The effect of cadmium on the digestive system of the teleost fish, Heteropneustes fossilis. Environmental Research 19, 221-230.

Sehar, A., Shafaqat, A., Uzma, S.A., Mujahid, F., Saima, A.B., Rehan, A., 2014. Effect of different heavy metal pollution on fish, Research Journal of Chemical and Environmental Sciences 2, 74-79.

Soylak, M., Erdogan, N.D., 2006. Copper (II)-rubeanic acid coprecipitation system for separation-preconcentration of trace metal ions in environmental samples for their flame atomic absorption spectrometric determinations. Journal of Hazardous Materials 137,1035-1041.

Stone, N.M., Thomforde, H.K., 2004. Understanding your fish pond water analysis report. Cooperative extension program, University of Arkansas at Pine bluff aquaculture/fisheries, USA. Pp. 1-4.

Swingle, H.S., 1967. Standardization of chemical analysis for waters and pond muds. FAO fish Report 4, pp. 397-421.

Warish, A.M., Ahmad, T., Hasan, N., 2017. A case study of Ground Water Quality Analysis Surrounding on Gurgaon Canal (NCR Mewat). International Research Journal of Engineering and Technology 4, 1800-1806.

Zanatta, A.S., Perbiche-Neves, G., Ventura, R., Ramos, I.P., Carvalho, E.D., 2010. Effects of a small fish cage farm on zooplankton assemblages (Cladocera and Copepoda: Crustacea) in a sub-tropical reservoir (SE Brazil). PanAmerican Journal of Aquatic Sciences 5, 530-536.

Visit us at: http://bosaljournals.com/chemint/ Submissions are accepted at: editorci@bosaljournals.com 